\title{
INTEGRATION OF INTERDISCIPLINARY SCIENTIFIC KNOWLEDGE IN TEACHING INVERSE PROBLEMS FOR DIFFERENTIAL EQUATIONS
}

\author{
V.S. Kornilov \\ Moscow city pedagogical university \\ 29, Sheremetyevskaya str., Moscow, 127521, Russian Federation
}

Problem and goal. In the process of teaching students inverse problems for differential equations, one of the important goals is to form students ' fundamental knowledge in the field of inverse problems, in the field of applied and computational mathematics; to develop mathematical creativity that allows students after graduation, working in research institutions, to successfully solve a variety of complex mathematical problems in the implementation of practical applied research.

Methodology. In the process of teaching students inverse problems for differential equations, the system of humanitarian-oriented training sessions is designed, the methods of rational reasoning are used, an individual approach to learning is implemented.

Results. Humanitarian-oriented training sessions on inverse problems for differential equations are aimed at creating situations that require students, according to the results of solving the inverse problem, to make logical conclusions of applied and humanitarian character, to overcome moral contradictions, to make a reasonable choice of the right position in society. The skills and experience gained in the course of training in the application of rational reasoning in the study of inverse problems for differential equations allow students not only to effectively investigate applied problems, but also to form fundamental knowledge in the field of applied mathematics. Individual approach in teaching inverse problems for differential equations acts as a didactic principle of training, education and development of students, taking into account the personal characteristics of students, the level of intellectual development, cognitive interests and other factors that affect the success of learning.

Conclusion. Humanitarian-oriented training sessions on inverse problems for differential equations, methods of rational reasoning, individual approach to learning allows the students to form a system of fundamental knowledge in inverse problems for partial differential equations, integrating multidisciplinary scientific knowledge, to identify humanitarian and scientific-educational potential of such learning, to justify the positive contribution of teaching inverse problems for differential equations in humanization and fundamentalization of mathematical education.

Key words: teaching inverse problems for differential equations, interdisciplinary scientific knowledge, scientific and educational potential of teaching inverse problems for differential equations, scientific and cognitive potential of students

Problem statement. Modern scientific methods and approaches to the study of the surrounding world are diverse and multifaceted. The researcher uses scientific methods of the world science on the basis of his professional knowledge and experience, goals and tasks for knowledge of processes and phenomena, their cause-effect relations, and widely uses interdisciplinary scientific knowledge. A philosopher studies the world through philosophical categories, a physicist through physical experiments, a chemist through 
chemical experiments. Mathematician explores the processes and phenomena occurring in the world through mathematical modeling, which is based in many cases using the equations of mathematical physics.

Mathematical modeling as a scientific method of studying the surrounding world in modern world science is one of the central places. This fact is explained by the fact that mathematical models have important from a scientific point of view properties, including scientific and cognitive potential and versatility. And the presence of modern computer technology allows mobile to explore and visualize solutions to a wide variety of mathematical models. It is no coincidence that mathematical modeling is included in the content of many disciplines of physics and mathematics and natural science areas of training of university students.

Mathematical modeling is widely used in the theory of inverse problems for differential equations. Scientific approaches and mathematical methods of inverse problems for differential equations as a scientific direction of modern applied mathematics are widely used in applied research (see, for example, $[1-3 ; 5-11 ; 13 ; 26-35]$ ). The rapid development in the 40-50-ies of the last century the theory and numerical methods for solving inverse problems for differential equations due largely proposed in 1943 A.N. Tikhonov physically justified concept of the correctness of the mathematical tasks formulated in 1956 by M.M. Lavrent'ev determining the conditional correctness of the mathematical tasks involving the use of additional information about the properties of the solution of this mathematical problem.

The great need for the application of the theory of inverse problems for differential equations in applied research is explained by the possibility of effective research of objects and processes of different nature, difficult or inaccessible to humans, determining their location, shape, structure of inclusions, etc., revealing their cause-effect relationships. All this became possible thanks to the use of modern information and telecommunication technologies. These circumstances explain the widespread introduction in the educational process of higher education students of physical and mathematical areas of training teaching inverse problems of mathematical physics (see, for example, $[4 ; 8 ; 9-12 ; 14-$ $25 ; 30 ; 33 ; 34])$.

One of the components of students' mathematical creativity is the scientific and cognitive potential, which allows in the process of solving various applied problems to independently master new interdisciplinary scientific knowledge, to better understand the basic laws of nature, to develop a scientific worldview. Mathematical models of inverse problems for differential equations are atypical mathematical problems that are typically incorrect tasks, search not template solutions which involves a deep analysis of the investigated physical process and its causality, requires rational thinking and creative approaches for constructing a system of integral equations inverse problems for differential equations, and in the future to prove theorems of existence, uniqueness and conditional correctness of the solution of inverse problems for differential equations.

Method of research. In the study of mathematical models of the IPDE, depending on their types, types and performances, students acquire the ability and skills to form new scientific knowledge about the world, about the physical processes and phenomena occurring in it and their cause-effect relationships. Given example. 
1. In the study of mathematical models of inverse problems of seismology, students acquire scientific knowledge about seismology, studying the nature of elastic oscillations of the Earth. Depending on the features in the formulation of such inverse problems, students have to analyze and operate with information about the properties of elastic field sources, the structure of the earth's interior, through which seismic waves propagate).

2. In the study of mathematical models of inverse problems of gravimetry and magnetometry students form new scientific knowledge, for example, about the characteristics of the sources of the observed on the earth's surface gravitational field, the continuation of potential fields towards the sources.

3. In the study of mathematical models of inverse problems of astrophysics, students acquire scientific knowledge about the interpretation of observations of close binary systems, the movement of a pair of stars under the influence of mutual attraction, the important characteristics of stars, etc.

4. In the study of mathematical models of inverse problems of photo image processing students gain scientific knowledge in the field of image recognition, reconstruction of blurred and defocused images, tomography.

5. In the study of mathematical models of inverse problems of electrodynamics, students receive scientific knowledge about the processing and interpretation of the results of measuring electromagnetic radiation created by various objects, about the sources of electromagnetic fields, about the forms of bodies on which the field is scattered, about the heterogeneity of the earth's environment, about the synthesis of the electromagnetic field, etc.

6. In the study of mathematical models of inverse problems of atmospheric optics, students receive scientific knowledge about the physical state of the atmosphere, the concentration of absorbing and scattering substances, the size and shape of aerosol particles, their composition and structure, the parameters of the fine structure of the spectrum, the radiation intensity, etc.

7. In the study of mathematical models of inverse problems of determining the density of heat sources, students acquire scientific knowledge about the density of radioactive heat sources, the thermal radiation on the surface of the Earth, the half-life of radioactive elements, etc.

8. In the study of mathematical models of inverse problems for differential equations of elasticity, students master the scientific knowledge in the field of linear theory of elasticity, in particular ball isotropy, ideal elasticity, linear relationship between strain and stress, small deformation, external surface and volume forces, the natural state of the body, etc.

When finding solutions to mathematical models of inverse problems for differential equations, students also acquire new scientific knowledge in the subject areas that are not included in the content of traditional mathematical disciplines of applied and computational mathematics, and can be acquired only in the process of teaching special courses. For clarity, we give examples.

1. In the study of mathematical models of inverse spectral problems, students acquire scientific knowledge in the field of spectral analysis, which consists in determining the operators of some of their spectral characteristics. Students realize that such mathematical models of inverse problems play a big role in applications of physics, quantum mechanics, 
Geophysics, meteorology, Radioelectronics, elasticity theory and other applications. In the process of solving such inverse problems, students master the method of spectral maps, the method of reference models, the method of transformation operator and other mathematical methods.

2. In the study of mathematical models of dynamic inverse problems for hyperbolic equations, students master the idea of the Volterra operator equation method, optimization method, linearization method, difference scheme reversal method and other methods. They develop skills and abilities to operate functional spaces, perform mathematical operations on generalized functions, linear operators. Experience is gained in the application of S.L. Sobolev's method, the method of scales of Banach spaces of analytical functions, methods of integral geometry, methods of tensor analysis, the theorem of S.V. Kovalevskaya, the theorem of S. Banach and other methods and theorems in the search for solutions to inverse problems for differential equations.

3 . In the study of mathematical models of inverse boundary value problems of Aerohydrodynamics, students acquire subject scientific knowledge, for example, in the design of wing profiles, which must have the necessary characteristics, master such fundamental concepts as source, vortex, flow, profile geometry, flowing profile, flow of inhibited layers, master methods of aerodynamic design and other methods. The students in the solution of such inverse problems master the mathematical methods of determining the shape of the profile when there is known on his circuit of the speed distribution, methods of flow ideal fluid, methods of the theory of analytical functions and other methods.

4. In the study of mathematical models of inverse problems for differential equations using approximate methods, students acquire deep scientific knowledge in the field of computational mathematics. Among such scientific knowledge - the theory of difference schemes, finite-difference methods, the method of run, iterative methods, the method of regularization Tikhonov, Newton-Kantorovich method, gradient methods, a discrete analogue of the Volterra operator equation with bounded Lipschitz-continuous kernel. Other methods of error estimation for approximate solutions of inverse problems for differential equations to exact solutions are also mastered. At the same time, students widely use computer technologies to implement computational algorithms for finding approximate solutions to inverse problems for differential equations, which demonstrate to students their efficiency and mobility in the study of applied problems.

Design of the system of humanitarian-oriented training sessions. A holistic study of the properties of physical objects requires a natural-shaped approach and a variety of integrative methods of their research. From the position of this approach there are subjective and humanitarian principles of knowledge about the world.

When designing a system of humanitarian-oriented training sessions on inverse problems for differential equations, mathematical and didactic analysis of the training content, selection of a system of modular inverse problems for differential equations, setting training goals and planning a system of training sessions on inverse problems for differential equations. Humanitarian-oriented training sessions on inverse problems for differential equations are aimed at creating situations that require students, according to the results of solving the inverse problem, to make logical conclusions of applied and 
humanitarian character, to overcome moral contradictions, to make a reasonable choice of the right position in society.

Students together with the teacher justify that a particular inverse problem has humanitarian potential, as the results of its solution can make logical conclusions, for example, about the ecology of the environment, the impact of functioning objects on human health and other conclusions. Such logical reflections contribute to the formation of students ' ecological culture, skills in the humanitarian analysis of the nature of pollution of the earth's environment and air space, the system of knowledge about the role of inverse problems for differential equations in the humanitarian analysis of the earth and water environment, air space.

Such classes involve students, both to the problem of humanitarization of mathematical education, and to the problem of moral responsibility to society for the consequences of practical implementation of applied research, which requires humanitarian analysis with the participation of experts-humanitarians. From this point of view, inverse problems for differential equations can be considered as a moral application to various physical, environmental, social, economic, and other processes and phenomena.

Methods of rational reasoning. One of the most important features of rational reasoning that distinguishes them from deductive reasoning is that the former may include "blurred" concepts. The resulting uncertainty does not preclude the characterization of reasoning as correct, or partially correct, or false, and the drawing of certain useful conclusions from them, since it is assumed that such reasoning is always perceived in the light of possible amendments to vagueness and subjectivity. Rational reasoning is advisable to apply when teaching inverse problems for differential equations.

Among such rational arguments:

1) hypotheses in solving inverse problems for differential equations;

2) refinements in the course of solving inverse problems for differential equations;

3 ) reasonable analogies in solving inverse problems for differential equations;

4) control of the closure of the obtained system of the inverse problem in the course of its solution;

5) understanding the physical properties of the object in the process of solving inverse problems for differential equations;

6) the role of estimates in solving inverse problems for differential equations;

7) analysis and interpretation of solutions of inverse problems for differential equations;

8) search for surprises in solving inverse problems for differential equations.

The skills and experience gained in the course of training in the application of rational reasoning in the study of inverse problems for differential equations allow students not only to effectively investigate applied problems, but also to form fundamental knowledge in the field of applied mathematics.

Individualization of learning. When individualizing students' learning, as a rule, such indicators as learning, learning, cognitive interests, professional orientation of learning are taken into account. Individual approach in teaching inverse problems acts as a didactic principle of training, education and development of students, taking into account the personal characteristics of students, the level of intellectual development, cognitive interests and other factors that affect the success of learning. Individual work of the student is one of the forms of implementation of this principle. 
Among the important forms of individual work of students when teaching inverse problems for differential equations are working on term papers and final qualifying works on inverse problems for differential equations; writing of abstracts on research articles on the inverse problems for differential equations; participation in scientific-research work on inverse problems for differential equations; participation in scientific seminars devoted to the inverse problems for differential equations; participation in student conferences; independent work on the implementation of individual learning tasks on inverse problems for differential equations; participation in student scientific circles, etc.

The implementation of an individual approach in teaching inverse problems for differential equations is based on such positions as:

- methods and forms of training and education should be chosen taking into account the individuality of students;

- individual approach requires compliance with psychological and pedagogical tact towards students;

- high-quality training of the student is provided by the daily activities of the teacher, built on the knowledge of the individual characteristics of each student of the group being trained.

Agreat contribution to the development of scientific and cognitive potential of students in the process of learning inverse problems for differential equations is made by their independent work, during which not only the new educational material is worked out, but also the special scientific literature is studied-scientific articles, materials of scientific conferences, published not only in Russian but also in English. At the same time, students master the scientific style of presentation of scientific material in such special literature, which differs significantly from the style of presentation of educational material in textbooks and educational literature.

During the independent work, students explore the issues of correctness of solutions of various inverse problems for differential equations, which are recommended by the teacher. Develop skills and abilities to formulate logical conclusions on the basis of the results of the study of inverse problems for differential equations. In the course of such scientific work, students may have their own ideas and approaches to the study of inverse problems for differential equations.

It is obvious that in this course of study, students develop both fundamental scientific knowledge on inverse problems for differential equations, applied mathematics, computational mathematics, and develop scientific and cognitive potential, which will help them to master new scientific knowledge and apply them in their future professional activities.

Results and discussion. Currently, with the development of computer science as a scientific discipline, gaining new positions in various fields of human activity information and mathematical modeling as one of the important tools of knowledge of the world. It is not surprising that today there is a great interest in the development of methodical systems of teaching computer science in the University, in which students learn innovative methods of scientific knowledge of various information processes. It is obvious that future specialists of various specialties, including in the field of applied mathematics, need not only to know the concepts and methods of information and mathematical modeling, but also to have an idea about the tools used in modeling. 
The rapid development of the theory and practice of inverse problems for differential equations is largely due to the possibility of effective study of objects and processes of different nature, difficult or inaccessible to man, determining their location, shape, structure of inclusions, etc., identifying their cause-effect relationships with the use of modern information and telecommunication technologies. According to V.G. Romanov, expressed by him in the 70s of the last century, the theory of inverse problems is the theory of information and involves information-mathematical processing of information about the solution of the studied applied problem. Therefore, knowledge of the theory and methodology of inverse problems is an important factor in the formation and development of information thinking among University students of physical and mathematical and natural science areas of training.

In the process of teaching inverse problems for differential equations, various mathematical models of inverse problems are studied using both analytical and numerical methods, interdisciplinary connections of such academic disciplines as analysis, algebra, geometry, differential equations (ordinary or partial derivatives), integral equations, numerical methods, computer science and other disciplines are realized.

Fundamental concepts of computer science in teaching inverse problems for differential equations. Modern applied mathematics is characterized by such features as the analysis of mathematical models, increasing the role of general mathematical structures, the spread of ideas of optimality, algorithmization, strengthening of business character, humanitarization and other features. In this connection, the implementation of interdisciplinary connections in the process of teaching inverse problems for differential equations is due to the need to integrate natural science and Humanities, which allows students to form a system of fundamental knowledge in the field of inverse problems, to understand their cognitive and humanitarian potential, to understand the epistemological processes in applied mathematics, to identify the basic concepts of Informatics as a scientific discipline. Such basic concepts of informatics include: information, modeling, formalization, algorithmization, computational experiment, syntax, semantics, computer graphics, information technology and other basic concepts of informatics.

The content of training of university students is largely determined by their professional orientation of training. In the process of such training, students explore various mathematical models of inverse problems using both ordinary differential equations and partial differential equations. It should be noted that in the process of teaching students are informed that the mathematical models of inverse problems for differential equations are universal and can describe processes of different nature. And this universalism increases the cognitive potential of such mathematical models. Students are explained that mathematical models of inverse problems are universal when they are syntactic in nature, when semantics, meaningful knowledge and the meaning of the simulated process remain outside of this mathematical model. In this case, it is difficult to conclude what specific process is described by this model.

Students realize that the methods of research of mathematical models of inverse problems, their cognitive potential can be used in the study of various nature applications. The subsequent analysis of the applied and humanitarian aspects of the obtained results of the inverse problem allows students to draw the appropriate logical conclusions about 
the process under study and, ultimately, to obtain new information, to study its properties and to understand its value.

When teaching students inverse problems for differential equations, attention is paid to numerical methods for their solution, since many inverse problems are nonlinear, which does not allow to obtain their exact solution. Then, usually a system of equations of the inverse problem is constructed, as a rule, in the form of integral equations, the solution of which is sought by means of iterative processes, which involve multiple solutions of the corresponding direct problems. In this case, numerical methods such as finite-difference methods, Newton-Kantorovich method, optimization methods, linearization method and other numerical methods are effective methods of finding approximate solutions of inverse problems for differential equations. In the process of learning inverse problems for differential equations, students at seminars and laboratory classes master various computational algorithms for finding approximate solutions to such inverse problems, including the use of computer technology.

Fundamental concepts of philosophy in teaching inverse problems for differential equations. When teaching inverse problems for differential equations to students, it is explained that their philosophical meaning is that unknown causes are calculated by known consequences. The coefficients or inhomogeneous terms of differential equations, initial or boundary conditions considered in conjunction with these differential equations can be considered as unknown reasons. As a consequence, various functionals from the solution of the mathematical model of the inverse problem can act. In the process of learning inverse problems for differential equations, students acquire the skills to study a variety of inverse problems, as a result of which they receive new information about the processes and phenomena under study, applied, humanitarian and philosophical analysis of which allows them to acquire new scientific knowledge about the world. Given example.

Considering in the classroom inverse problems for the system of Maxwell's equations, to the understanding of students ' teachers are given information that the reasons for such problems are, in particular, the coefficients of dielectric and magnetic permeability, electrical conductivity of the earth's environment, and the consequences are additional information about the solution of the relevant direct problems. Having such knowledge, studying inverse problems by mathematical methods, students form scientific knowledge about the heterogeneous structure of the earth's environment, its deep properties. Such scientific knowledge is widely used in seismology, geoelectrics, gravimetry, electrodynamics and other scientific fields; in the search for minerals, in industry.

When learning to solve inverse problems of sound radiation in underwater acoustics, for example, linear and nonlinear inverse problems for the Helmholtz equation, students are explained that the reasons may be, in particular, the unknown density of volume sources, unknown variable coefficients of the differential equation and other parameters, and as a consequence, for example, information about the emitted acoustic field. Such information allows students to form scientific knowledge about the deep properties of the World ocean in the studies of such inverse problems. Such scientific knowledge can be used in research of the ocean floor, the study of marine natural disasters, hydrogeological modeling and other scientific research.

Implementation of interdisciplinary scientific relations in teaching inverse problems for differential equations allows students to form deep subject theoretical knowledge, 
acquire skills and abilities of using mathematical methods for the study of applied problems. Students are able to carry out applied and humanitarian analysis of solutions of inverse problems for differential equations, to develop scientific worldview and mathematical creativity, to replenish their scientific knowledge in applied and computational mathematics, as well as in the field of such fundamental concepts of philosophy as cause and effect.

In the process of teaching inverse problems for differential equations, attention is paid to the philosophical aspects of the information phenomenon. Realizing the philosophical aspects of the identified in the solution of inverse problems of cause-effect relationships and the phenomenon of new information, students understand that the theory of inverse problems for differential equations is related to such methods of human knowledge as theory, experiment and philosophy. Philosophical understanding of cause-effect relationships and the concept of information helps students to master the methodological possibilities in understanding the surrounding reality, to understand that the information acquired as a result of the solution of the inverse problem is connected with the fundamental philosophical questions of natural science.

The analysis of applied, humanitarian and philosophical aspects of the obtained results of solving inverse problems for differential equations allows students to make appropriate logical conclusions about the process under study, to comprehend the scientific and humanitarian value of the new information obtained.

Conclusion. Integration of interdisciplinary scientific knowledge in the process of learning inverse problems for differential equations allows to identify the humanitarian and scientific-educational potential of such training, to identify the contribution of training in humanitarization and fundamentalization of applied mathematical education.

\section{LITERATURE}

[1] Агранович 3.С., Марченко В.А. Обратная задача теории рассеяния: монография. Харьков: Изд-во Харьковского университета, 1960. 268 с.

[2] Аниконов Ю.Е., Пестов Л.Н. Формулы в линейных и нелинейных задачах томографии: монография. Новосибирск: НГУ, 1990. 64 с.

[3] Белищев М.И., Благовещенский А.С. Динамические обратные задачи теории волн: монография. СПб.: СпбГУ, 1999. 266 с.

[4] Бидайбеков Е.Ы., Корнилов В.С., Камалова Г.Б. Обучение будущих учителей математики и информатики обратным задачам для дифференциальных уравнений // Вестник Московского городского педагогического университета. Серия «Информатика и информатизация образования». 2014. № 3 (29). С. 57-69.

[5] Блехман И.М., Мышкис А.Д., Пановко Я.Г. Прикладная математика: Предмет, логика, особенности подходов. М.: КомКнига, 2005. 376 с.

[6] Бухгейм А.Л. Введение в теорию обратных задач: монография. Новосибирск: Наука, Сибирское отделение, $1988.181 \mathrm{c.}$

[7] Гончарский А.В., Черепашук А.М., Ягода А.Г. Численные методы решения обратных задач астрофизики: монография. М.: Наука, 1978. 335 с.

[8] Денисов А.М. Введение в теорию обратных задач: учеб. пособие. М.: Изд-во Московского университета, 1994. $207 \mathrm{c}$.

[9] Кабанихин С.И. Обратные и некорректные задачи: учебник для студентов вузов. Новосибирск: Сибирское научное издательство, 2009. 458 с. 
[10] Корнилов B.C. О междисциплинарном характере исследований причинно-следственных обратных задач // Вестник Московского городского педагогического университета. Серия «Информатика и информатизация образования». 2004. № 1 (2). С. 80-83.

[11] Корнилов B.C. Некоторые обратные задачи идентификации параметров математических моделей: учеб. пособие. М.: МГПУ, 2005. 359 с.

[12] Корнилов B.C. Обучение обратным задачам для дифференциальных уравнений как фактор гуманитаризации математического образования: монография. М.: МГПУ, 2006. 320 с.

[13] Корнилов В.С. Гуманитарные аспекты вузовской системы прикладной математической подготовки // Наука и школа. 2007. № 5. С. 23-28.

[14] Корнилов B.C. Гуманитарный анализ математических моделей обратных задач // Известия Курского государственного технического университета. 2008. № 3 (24). С. 60-65.

[15] Корнилов В.С. Психологические аспекты обучения обратным задачам для дифференциальных уравнений // Наука и школа. 2008. № 3. С. 45-46.

[16] Корнилов B.C. Лабораторные занятия как форма организации обучения студентов фрактальным множествам // Вестник Московского городского педагогического университета. Серия «Информатика и информатизация образования». 2012. № 1 (23). С. 60-63.

[17] Корнилов B.C. Обратные задачи в содержании обучения прикладной математике // Вестник Российского университета дружбы народов. Серия «Информатизация образования». 2014. № 2. С. 109-118.

[18] Корнилов B.C. Обучение студентов обратным задачам математической физики как фактор формирования фундаментальных знаний по интегральным уравнениям // Бюллетень лаборатории математического, естественнонаучного образования и информатизации. Рецензируемый сб. науч. тр. Самара: Самарский филиал МГПУ, 2015. Том VI. С. 251-257.

[19] Корнилов B.C. Обучение студентов обратным задачам для дифференциальных уравнений как фактор формирования компетентности в области прикладной математики // Вестник Российского университета дружбы народов. Серия «Информатизация образования». 2015. № 1. С. 63-72.

[20] Корнилов В.C. Формирование фундаментальных знаний будущих учителей информатики и математики по функциональному анализу при обучении обратным задачам математической физики // Вестник Московского городского педагогического университета. Серия «Информатика и информатизация образования». 2015. № 3 (33). С. 72-82.

[21] Корнилов В.C. Реализация научно-образовательного потенциала обучения студентов вузов обратным задачам для дифференциальных уравнений // Казанский педагогический журнал. 2016. № 6. С. 55-59.

[22] Корнилов В.С. Базовые понятия информатики в содержании обучения обратным задачам для дифференциальных уравнений // Вестник Российского университета дружбы народов. Серия: Информатизация образования. 2016. № 1. С. 70-84.

[23] Корнилов B.C. Теория и методика обучения обратным задачам для дифференциальных уравнений: монография. М.: Изд-во «ОнтоПринт», 2017. 500 с.

[24] Корнилов B.C. Формирование фундаментальных знаний по математическому моделированию при обучении обратным задачам для дифференциальных уравнений // Вестник Московского городского педагогического университета. Серия «Информатика и информатизация образования». 2017. № 1 (39). С. 92-99.

[25] Корнилов B.C. Философская составляющая научно-образовательного потенциала обучения обратным задачам математической физики // Вестник Московского городского педагогического университета. Серия «Информатика и информатизация образования». 2018. № 1 (43). С. 59-65.

[26] Лаврентьев М.М., Романов В.Г., Шишатский С.П. Некорректные задачи математической физики и анализа: монография. М.: Наука, 1980. 286 с.

[27] Левченко И.В., Корнилов В.С., Беликов В.В. Роль информатики в подготовке специалистов по прикладной математике // Вестник Московского городского педагогического университета. Серия «Информатика и информатизация образования». 2009. № 2 (18). С. 108 112. 
[28] Прилепко А.И. Избранные вопросы в обратных задачах математической физики / Условно-корректные задачи математической физики и анализа. Новосибирск: Наука, Сибирское отделение, 1992. С. 151-162.

[29] Романов В.Г. Некоторые обратные задачи для уравнений гиперболического типа: монография. Новосибирск: Наука, 1972. 164 с.

[30] Романов В.Г. Обратные задачи для дифференциальных уравнений: спецкурс для студентов НГУ. Новосибирск: НГУ, 1973. 252 с.

[31] Романов В.Г. Обратные задачи математической физики: монография. М.: Наука, 1984. $264 \mathrm{c}$.

[32] Самарский А.А., Вабишевич П.Н. Численные методы решения обратных задач математической физики: монография. М.: УРСС, 2004. 478 с.

[33] Тимофеев Ю.М., Поляков А.В. Математические аспекты решения обратных задач атмосферной оптики: учеб. пособие. СПб.: Изд-во Санкт-Петербургского университета, 2001. $188 \mathrm{c}$.

[34] Юрко В.А. Введение в теорию обратных спектральных задач: учебное пособие. М.: Физматлит, 2007. $384 \mathrm{c.}$

[35] Яхно В.Г. Обратные задачи для дифференциальных уравнений упругости: монография. Новосибирск: Наука, Сибирское отделение, 1990. 303 с.

(C) Kornilov V.S., 2018

\title{
Article history:
}

Received: 17 may, 2018

Accepted: 20 June, 2018

\section{For citation:}

Kornilov V.S. (2018). Integration of interdisciplinary scientific knowledge in teaching inverse problems for differential equations. RUDN Journal of Informatization Education, 15 (2), 304-318. DOI 10.22363/2312-8631-2018-15-3-304-318

\section{Bio Note:}

Kornilov Viktor Semenovich, doctor of pedagogical sciences, candidate of physical and mathematical sciences, full professor, deputy head of the department of informatization of education of the Moscow city pedagogical university. Contact information: e-mail: vs_kornilov@mail.ru

\section{ИНТЕГРАЦИЯ МЕЖДИСЦИПЛИНАРНЫХ НАУЧНЫХ ЗНАНИЙ ПРИ ОБУЧЕНИИ ОБРАТНЫМ ЗАДАЧАМ ДЛЯ ДИФФЕРЕНЦИАЛЬНЫХ УРАВНЕНИЙ}

\author{
В.С. Корнилов \\ Московский городской педагогический университет \\ Российская Федерация, 127521, Москва, ул. Шереметьевская, 29
}

\footnotetext{
Проблема и цель. В процессе обучения студентов обратным задачам для дифференциальных уравнений реализуется одна из важных целей - сформировать у студентов фундаментальные знания в области обратных задач, в области прикладной и вычислительной математики; развить математические творческие способности, позволяющие студентам после окончания обучения, работая в научно-исследовательских учреждениях, успешно решать разнообразные сложные математические задачи при реализации на практике прикладных исследований.
} 
Методология. В процессе обучения студентов обратным задачам для дифференциальных уравнений применяется разработанная система гуманитарно-ориентированных учебных занятий, используются методы рационального мышления, реализуется индивидуальный подход к обучению.

Результаты. Гуманитарно-ориентированные учебные занятия по обратным задачам для дифференциальных уравнений направлены на создание ситуаций, требующих от студентов, по результатам решения обратной задачи, сделать логические выводы прикладного и гуманитарного характера, преодолеть нравственные противоречия, сделать обоснованный выбор правильной позиции в обществе. Приобретенные в процессе обучения навыки и опыт применения рациональных рассуждений при исследовании обратным задачам для дифференциальных уравнений позволяют студентам не только эффективно исследовать прикладные задачи, но и формировать фундаментальные знания в области прикладной математики. Индивидуальный подход в обучении обратным задачам для дифференциальных уравнений выступает как дидактический принцип обучения, воспитания и развития студентов, учитывающий личностные особенности обучаемых, уровень интеллектуального развития, познавательные интересы и другие факторы, оказывающие влияние на успешность обучения.

Заключение. Гуманитарно-ориентированные учебные занятия по обратным задачам для дифференциальных уравнений, методы рациональных рассуждений, индивидуальный подход в обучении позволяют сформировать у студентов систему фундаментальных знаний по обратным задачам для дифференциальных уравнений, интегрировать междисциплинарные научные знания, выявить гуманитарный и научно-образовательный потенциал такого обучения, обосновать позитивный вклад обучения обратным задачам для дифференциальных уравнений в гуманитаризацию и фундаментализацию прикладного математического образования.

Ключевые слова: обучение обратным задачам для дифференциальных уравнений, междисциплинарные научные знания, научно-образовательный потенциал обучения обратным задачам для дифференциальных уравнений, научно-познавательный потенциал студентов

\section{REFERENCES}

[1] Agranovich Z.S., Marchenko V.A. Obratnaya zadacha teorii rasseyaniya [the inverse problem of scattering theory]: monografiya. Har'kov: Izd-vo Har'kovskogo universiteta, 1960. 268 p.

[2] Anikonov YU.E., Pestov L.N. Formuly v linejnyh i nelinejnyh zadachah tomografii [Formulas in linear and nonlinear tomography problems]: monografiya. Novosibirsk: NGU, 1990. 64 p.

[3] Belishev M.I., Blagoveshchenskij A.S. Dinamicheskie obratnye zadachi teorii voln [Dynamic inverse problems of wave theory]: monografiya. SPb.: SpbGU, 1999. 266 p.

[4] Bidaibekov E.S., Kornilov V.S., Kamalova G.B. Obuchenie budushhih uchitelej matematiki i informatiki obratnym zadacham dlja differencial'nyh uravnenij [The training of future teachers of mathematics and Informatics inverse problems for differential equations]. Vestnik Moskovskogo gorodskogo pedagogicheskogo universiteta. Serija «Informatika i informatizacija obrazovanija» [Bulletin of the Moscow city pedagogical university. "Informatics and Informatization of Education" series]. 2014. No. 3 (29). Pp. 57-69.

[5] Blehman I.M., Myshkis A.D., Panovko Ja.G. Prikladnaja matematika:predmet, logika, osobennosti podhodov [Applied mathematics: the subject of logic, especially the approaches]. M.: KomKniga, 2005. $376 \mathrm{p}$.

[6] Buhgejm A.L. Vvedenie v teoriju obratnyh zadach [Introduction to the theory of inverse problems]: monografiya. Novosibirsk: Nauka, Sibirskoe otdelenie, 1988. 181 p.

[7] Goncharsky A.V., Cherepashchuk A. M., Yagola A. G. CHislennye metody resheniya obratnyh zadach astrofiziki [Numerical methods for solving inverse problems of astrophysics]: monografiya. M.: Nauka, 1978. 335 p.

[8] Denisov A.M. Vvedenie v teoriyu obratny zadach [Introduction to the theory of inverse problems]: uchebnoe posobie. M.: Izd-vo Moskovskogo universiteta, 1994. 207 p.

[9] Kabanikhin S.I. Obratnye i nekorrektnye zadachi [Inverse and incorrect problems]: uchebnoe posobie. Novosibirsk: Siberian scientific publishing house, 2009. 458 p. 
[10] Kornilov V.S. O mezhdisciplinarnom haraktere issledovanij prichinno-sledstvennyh obratnyh zadach [About cross-disciplinary character of researches of cause and effect inverse problems]. Vestnik Moskovskogo gorodskogo pedagogicheskogo universiteta. Serija «Informatika i informatizacija obrazovanija» [Bulletin of the Moscow city pedagogical university. "Informatics and Informatization of Education" series]. 2004. No. 1 (2). Pp. 80-83.

[11] Kornilov V.S. Nekotorye obratnye zadachi identifikacii parametrov matematicheskih modelej [Some inverse problem of identifying parameters of mathematical models]: uchebnoe posobie. M.: MGPU, 2005. $359 \mathrm{p}$.

[12] Kornilov V.S. Obuchenie obratnym zadacham dlya differencial'nyh uravnenij kak faktorgumanitarizacii matematicheskogo obrazovaniya [Training in inverse problems for differential equations as a factor of humanitarization of mathematical education]: monografiya. M.: MGPU, 2006. 320 p.

[13] Kornilov V.S. Gumanitarnye aspekty vuzovskoj sistemy prikladnoj matematicheskoj podgotovki [The humanitarian aspects of the university system of applied mathematical preparation of]. Nauka i shkola [Science and school]. 2007. No. 5. Pp. 23-28.

[14] Kornilov V.S. Gumanitarnyj analiz matematicheskih modelej obratnyh zadach [Humanitarian analysis of mathematical models of inverse problems]. Izvestiya Kurskogo gosudarstvennogo tekhnicheskogo universiteta [News of Kursk state technical university]. Kursk: KGTU, 2008. No. 3 (24). Pp. 60-65.

[15] Kornilov V.S. Psihologicheskie aspekty obucheniya obratnym zadacham dlya differencial'nyh uravnenij [Psychological aspects of teaching inverse problems for differential equations]. Nauka $i$ shkola [Science and school]. 2008. No. 3. Pp. 45-46.

[16] Kornilov V.S. Laboratornye zanjatija kak forma organizacii obuchenija studentov fraktal'nym mnozhestvam [Laboratory sessions as a form of organization of teaching students fractal sets]. Vestnik Moskovskogo gorodskogo pedagogicheskogo universiteta. Serija «Informatika i informatizacija obrazovanija» [Bulletin of the Moscow city pedagogical university. "Informatics and Informatization of Education" series]. 2012. No. 1 (23). Pp. 60-63.

[17] Kornilov V.S. Obratnye zadachi v soderzhanii obucheniya prikladnoj matematike [Inverse problems in the content of teaching applied mathematics]. Vestnik Rossijskogo universiteta druzhby narodov. Serija «Informatizacija obrazovanija» [Bulletin of the Russian university of friendship of the people. "Education Informatization" series]. 2014. No. 2. Pp. 109-118.

[18] Kornilov V.S. Obuchenie studentovobratnym zadacham matematicheskojfiziki kakfactor formirovanija fundamental'nyh znanij po integral'nym uravnenijam [Training of students in the inverse problems of mathematical physics as factor of formation of fundamental knowledge of the integrated equations]. Bjulleten' laboratorii matematicheskogo, estestvennonauchnogo obrazovanija $i$ informatizacii. Recenziruemyj sbornik nauchnyh trudov [Bulletin of laboratory of mathematical, natural-science education and informatization. The reviewed collection of scientific work]. Samara: Samarskij filial MGPU, 2015. T. VI. Pp. 251-257.

[19] Kornilov V.S. Obuchenie studentov obratnym zadacham dlja differencial'nyh uravnenij kak factor formirovanija kompetentnosti voblasti prikladnoj matematiki [Students learning the inverse problems for differential equations as a factor of formation of competence in the field of applied mathematics]. Vestnik Rossijskogo universiteta druzhby narodov. Serija «Informatizacija obrazovanija» [Bulletin of the Russian university of friendship of the people. "Education Informatization" series]. 2015. No. 1. Pp. 63-72.

[20] Kornilov V.S. Formirovanie fundamental'nyh znanij budushchih uchitelej informatiki i matematiki po funkcional'nomu analizu pri obuchenii obratnym zadacham matematicheskojfiziki [the Formation of the fundamental knowledge of future teachers of Informatics and mathematics functional analysis when teaching inverse problems of mathematical physics]. Vestnik Moskovskogo gorodskogo pedagogicheskogo universiteta. Serija «Informatika i informatizacija obrazovanija» [Bulletin of the Moscow city pedagogical university. "Informatics and Informatization of Education" series]. 2015. No. 3 (33). Pp. 72-82.

[21] Kornilov V.S. Realizacija nauchno-obrazovatel'nogo potenciala obuchenija studentov vuzov obratnym zadacham dlja differencial'nyh uravnenij [Realization of scientific and educational potential of 
training of students of higher education institutions in the inverse problems for the differential equations]. Kazanskij pedagogicheskij zhurnal [Kazan pedagogical journal]. 2016. No. 6. Pp. 5559.

[22] Kornilov V.S. Bazovye ponyatiya informatiki v soderzhanii obucheniya obratnym zadacham dlya differencial'nyh uravnenij [The basic concepts of Informatics in the content of education inverse problems for differential equations]. Vestnik Rossijskogo universiteta druzhby narodov. Serija «Informatizacija obrazovanija» [Bulletin of the Russian university of friendship of the people. "Education Informatization" series]. 2016. No. 1. Pp. 70-84.

[23] Kornilov V.S. Teorija i metodika obuchenija obratnym zadacham dlja differencial'nyh uravnenij [Theory and technique of training to the inverse problems for differential equations]: monografija. M.: Izd-vo «OntoPrint», 2017. 500 p.

[24] Kornilov V.S. Formirovanie fundamental'nyh znanij po matematicheskomu modelirovaniyu pri obuchenii obratnym zadacham dlya differencial'nyh uravnenij [Formation of the fundamental knowledge on mathematical modeling in teaching inverse problems for differential equations]. Vestnik Moskovskogo gorodskogo pedagogicheskogo universiteta. Serija «Informatika i informatizacija obrazovanija» [Bulletin of the Moscow city pedagogical university. "Informatics and Informatization of Education" series]. 2017. No. 1 (39). Pp. 92-99.

[25] Kornilov V.S. Filosofskaya sostavlyayushchaya nauchno-obrazovatel'nogo potenciala obucheniya obratnym zadacham matematicheskoj fiziki [Philosophical component of scientific and educational potential of learning inverse problems of mathematical physics]. Vestnik Moskovskogo gorodskogo pedagogicheskogo universiteta. Serija «Informatika i informatizacija obrazovanija» [Bulletin of the Moscow city pedagogical university. "Informatics and Informatization of Education" series]. 2018. No. 1 (43). Pp. 59-65.

[26] Lavrentyev M.M., Romanov V.G., Shishatsky S.P. Nekorrektnye zadachi matematicheskoj fiziki i analiza [Ill-Posed problems of mathematical physics and analysis]: monograph. M.: Nauka, 1980. $286 \mathrm{p}$.

[27] Levchenko I.V., Kornilov V.S., Belikov V.V. Rol' informatiki vpodgotovke specialistov po prikladnoj matematike [The role of Informatics in the training of specialists in applied mathematics]. Vestnik Moskovskogo gorodskogo pedagogicheskogo universiteta. Serija «Informatika i informatizacija obrazovanija» [Bulletin of the Moscow city pedagogical university. "Informatics and Informatization of Education" series]. 2009. No. 2 (18). Pp. 108-112.

[28] Prilepko A.I. Izbrannye voprosy v obratnyh zadachah matematicheskoj fiziki [Selected questions in inverse problems of mathematical physics]. Uslovno-korrektnye zadachi matematicheskoj fiziki $i$ analiza [Conditionally correct problems of mathematical physics and analysis]. Novosibirsk: Nauka, Sibirskoe otdelenie, 1992. Pp. 151-162.

[29] Romanov V.G. Nekotorye obratnye zadachi dlya uravnenij giperbolicheskogo tipa [Some inverse problems for equations of hyperbolic type]: monografiya. Novosibirsk: Nauka, 1972. 164 p.

[30] Romanov V.G. Obratnye zadachi dlya differencial'nyh uravnenij [Inverse problems for differential equations]: speckurs dlya studentov NGU. Novosibirsk: NGU, 1973. 252 p.

[31] Romanov V.G. Obratnye zadachi matematicheskojfiziki [Inverse problems of mathematical physics]: monografija. M.: Nauka, 1984. 264 p.

[32] Samarskij A.A., Vabishevich P.N. Chislennye metody reshenija obratnyh zadach matematicheskoj fiziki [Numerical methods of the solution of the inverse problems of mathematical physics]: monografija. M.: Editorial URSS, 2004. 480 p.

[33] Timofeev Yu.M., Polyakov A.V. Matematicheskie aspekty resheniya obratnyh zadach atmosfernoj optiki [Mathematical aspects of solving inverse problems of atmospheric optics]: uchebnoe posobie. SPb.: Izd-vo Sankt-Peterburgskogo universiteta, 2001. 188 p.

[34] Yurko V.A. Vvedenie v teoriyu obratnyh spektral'nyh zadach [Introduction to the theory of inverse spectral problems]: textbook. M.: Fizmatlit, 2007. 384 p.

[35] Yakhno V.G. Obratnye zadachi dlya differencial'nyh uravnenij uprugosti [Inverse problems for differential equations of elasticity]: monografiya. Novosibirsk: Nauka, Sibirskoe otdelenie, 1990. $303 \mathrm{p}$. 


\section{История статьи:}

Дата поступления в редакцию: 17 мая 2018

Дата принятия к печати: 20 июня 2018

\section{Для щитирования:}

Корнилов В.С. Интеграция междисциплинарных научных знаний при обучении обратным задачам для дифференциальных уравнений // Вестник Российского университета дружбы народов. Серия «Информатизация образования». 2018. Т. 15. № 3. С. 304-318. DOI 10.22363/2312-8631-2018-15-3-304-318

Сведения об авторе:

Корнилов Виктор Семенович, доктор педагогических наук, кандидат физико-математических наук, профессор, заместитель заведующего кафедрой информатизации образования Московского городского педагогического университета. Контактная информация: e-mail: vs_kornilov@mail.ru 